\title{
RAPUHNYA BENTENG KEADILAN DI INDONESIA (Kajian terhadap kekuasaan kehakiman (peradilan) sebagai benteng keadilan dalam Sistem Peradilan Pidana)
}

\author{
Abdul Kholiq \\ Universitas Buana Perjuangan Karawang \\ Email: abdulkholiq@ubpkarawang.ac.id
}

\begin{abstract}
Abstrak
Penegakan hukum dengan menggunakan sistem peradilan pidana berarti mengimplementasikan bekerjanya dalam setiap tahapan peradilan pidana, yaitu tahapan penyidikan, penuntutan, peradilan dan pelaksanaan putusan. Permasalahan konseptual yang menyangkut struktur penegakan hukum pidana, bersumber dari sistem penegakan hukum yang dibangun berdasarkan desain konstitusional. Pasca amandemen ke III terhadap Undang-Undang Dasar 1945, yang kemudian juga diikuti terbitnya Undang-Undang Nomor 48 Tahun 2009 Tentang Kekuasaan Kehakiman sebagai peraturan pelaksana, terhadap koreksi pada Kekuasaan Kehakiman. Kekuasaan kehakiman dijalankan dan dipegang oleh badan peradilan, hal ini sesuai dalam teori maupun ketentuan dalam peraturan perundang-undangan. Badan peradilan di Indonesia yang menjalankan kekuasaan kehakiman berdasarkan hasil amandemen Undang-Undang Dasar 1945 adalah Mahkamah Agung, Mahkamah Konstitusi dan pengadilan-pengadilan tingkat lebih rendah yang di bawah Mahkamah Agung. Ketentuan tersebut juga diatur secara eksplisit di dalam Undang-Undang Dasar 1945 Pasal 24 Ayat (2). Pengadilan selama ini dijadikan sebagai suatu simbolik bagi masyarakat untuk mencapai tujuan-tujuan hukum khususnya keadilan dari permasalahan atau sengketa-sengketa hukum yang harus diselesaikan. Supremasi hukum akan dapat berjalan secara maksimal tatkala komponenkomponen dalam penegakan hukum yang tersistem ke dalam bentuk sistem peradilan pidana yang integral. Dalam penegakan hukum yang juga berhubungan dengan kekuasaan kehakiman, maka peran yang utama yaitu hakim-hakim pengadilan.
\end{abstract}

Kata Kunci: Penegakan Hukum, Kekuasaan

Kehakiman, Sistem Peradilan Pidana.

\begin{abstract}
Law enforcement by using the criminal justice system means implementing its work at every stage of criminal justice, namely the stages of investigation, prosecution, trial and implementation of decisions. Conceptual issues concerning the structure of criminal law enforcement are derived from a law enforcement system that is built on constitutional design. After the third amendment to the Constitution of 1945, which was also followed by the issuance of Law Number 48 of 2009 on Concerning Judicial Power as the implementing regulation, against correction to Judicial Power. Judicial power is carried out and held by the judiciary, this is in accordance with the theory and provisions in the legislation. Judicial bodies in Indonesia that exercise judicial authority based on the amendments to the Constitution of 1945 are the Supreme Court, the Constitutional Court and lower-level courts under the Supreme Court. These provisions are also explicitly regulated in the Constitution of 1945 in Article 24 Paragraph (2). The court has been used as a symbolic for the community to achieve legal objectives, especially justice from problems or legal disputes that must be resolved. The supremacy of law will be able to run maximally when the components in systemic law enforcement are in the form of an integral criminal justice system. In law enforcement which also relates to judicial power, the main role is court judges.
\end{abstract}

Keyword: Law Enforcement, Judicial Power, Criminal Justice System. 


\section{PENDAHULUAN}

Permasalahan penegakan hukum (law enforcement) yang terjadi pada ruang lingkup hukum pidana di Indonesia masih belum menunjukkan keberhasilan yang memberikan keadilan. Penanggulangan kejahatan yang terjadi hanya mengupayakan kegiatan yang tersistematis atau prosedural dalam kerangka sistem peradilan pidana. Jika dipahami dalam penegakan hukum pidana dapat dilakukan melalui beberapa jalur diantaranya menggunakan jalur penal dan non-penal. Dalam upaya penanggulangan kejahatan yang dilakukan melalui sarana penal (hukum pidana) memiliki tahapan-tahapan yang harus dilalui setiap perkara-perkara yang akan diselesaikan. Tahapan tersebut antara lain penyidikan, penuntutan, peradilan dan pelaksanaan putusan, sedangkan penanggulangan kejahatan yang dapat dilakukan melalui sarana non penal dapat dilakukan dengan bentuk mediasi, restorative justice dan sebagainya. Hal tersebut hanya menekankan penyelesaian perkara dengan mempertemukan antar pihak-pihak yang berperkara yaitu pelaku (offender) dan korban (victim), namun masyarakat masih kurang pengetahuan akan adanya penyelesaian perkara melalui non penal atau diluar peradilan.

Sistem peradilan pidana merupakan suatu sistem yang terbuka, karena telah tampak adanya pengaruh yang sangat besar dari masyarakat dalam proses untuk mencapai tujuan bersama yang bersangkutan. Dengan demikian adanya beberapa faktor-faktor yang berada di luar sistem dapat berupa: ekonomi, politik, pendidikan dan teknologi yang berpengaruh terhadap proses-proses pencapaian tujuan tersebut. Sistem peradilan pidana itu bersifat indeterministik (tidak dapat menentukan diri sendiri secara penuh) juga bersifat probalistik (terbuka pada setiap kemungkinan yang dapat terjadi dalam proses pencapaian tujuan).

Penegakan hukum dengan menggunakan sistem peradilan pidana berarti mengimplementasikan bekerjanya dalam setiap tahapan peradilan pidana, yaitu tahapan penyidikan, penuntutan, peradilan dan pelaksanaan putusan. $^{1}$ Dalam melaksanakan kegiatan tersebut

1 Muladi, Kapita Selekta Sistem Peradilan Pidana, Semarang : Badan penerbit UNDIP. Tahun 1995, hal vii 
memerlukan ketergantungan dan saling mendukung agar pelaksanaan peradilan pidana memberikan suatu keadilan yang dibutuhkan oleh masyarakat pada umumnya. Selain perlu adanya hubungan kerjasama secara aktif yang dilakukan dalam setiap tahapan, juga memerlukan konsep keterpaduan sehingga muncul sistem peradilan pidana terpadu (Intergrated criminal justice system). Jika tidak adanya suatu sistem yang berjalan secara efektif dan efisien dalam setiap sub sistem peradilan pidana maka akan memberikan dampak bekerjanya sistem secara keseluruhan. Adanya keterpaduan sistem agar dalam penyelesaian perkara dapat memperhatikan keadilan secara substansial yang diharapkan oleh pencari keadilan.

Peradilan merupakan segala sesuatu yang berhubungan dengan tugas Negara menegakkan hukum dan keadilan, yang menurut Pasal 24 Undang-Undang Dasar 1945, peradilan itu dilakukan oleh Mahkamah Agung dan Badan-badan Pengadilan yang dibentuk dengan Undang - Undang. ${ }^{2}$

\footnotetext{
2 Subekti dan Tjitrosoedibio. Kamus Hukum. Jakarta : Pradya Paramita. Tahun 1972, hal 83
}

Sedangkan pengertian dari Pengadilan adalah badan yang melakukan peradilan, yaitu memeriksa dan memutus sengketa-sengketa hukum dan pelanggaran-pelanggaran hukum atau undang-undang. ${ }^{3} \quad$ Fungsi pengadilan sebagai institusi yang mempunyai peran dalam penegakan hukum (law enforcement) dan keadilan (justice), serta menjamin perlindungan hak asasi manusia pada saat ini telah mengalami keterpurukan yang disebabkan karena adanya rekayasa, diskriminatif dan ketidakadilan sebagai hasil korupsi pengadilan (judicial corruption) yang populer disebut mafia peradilan. ${ }^{4}$

Permasalahan konseptual yang menyangkut struktur penegakan hukum pidana, bersumber dari sistem penegakan hukum yang dibangun berdasarkan desain konstitusional. Pasca amandemen ke III terhadap Undang-Undang Dasar 1945, yang kemudian juga diikuti terbitnya Undang-Undang Nomor 48 Tahun 2009 Tentang Kekuasaan Kehakiman sebagai peraturan pelaksana, terhadap koreksi

\footnotetext{
${ }^{3}$ Ibid, hal, 82

4 Donny Daradono. Uang, Ideologi, Jabatan dalam Mafia Peradilan, Reduksi terhadap The Political. Jurnal Kajian Politik Lokal dan Studi Humaniora. Salatiga: Yayasan PercikTahun 2007. hal 5
} 
pada Kekuasaan Kehakiman. Bentuk kekuasaan kehakiman dalam UndangUndang 1945 Amandemen III, sebagaimana tersebut dalam Bab IX, meliputi Mahkamah Agung dan peradilan dibawahya, Mahkamah Konstitusi dan Komisi Yudisial. Keberadaan Komisi Yudisial dalam Bab IX dengan bersama Mahkamah Agung dan Mahkamah Konstitusi, pada dasarnya didesain sebagai lembaa yang melaksanakan kekuasaan kehakiman, yaitu sebagai supporting element yang berhubungan dengan Mahkamah Agung dan Mahkamah Konstitusi untuk memperkuat prinsip kekuasaan kehakiman yang independen dan imparsial (independent and impartial) guna dalam menegakan hukum dan keadilan. $^{5}$

Pelaksanaan kekuasaan kehakiman yang dilakukan dalam sebuah peradilan pidana masih bersifat parsial, hal ini menyebabkan lemahnya prinsip indepedensi dan imparsialitas peradilan serta lemahnya pengawasan secara internal dan eksternal dari

\footnotetext{
5 J. Pajar Widodo. Reformasi Sistem Peradilan Pidana Dalam Rangka Penanggulangan Mafia Peradilan. Jurnal Dinamika Hukum Vol 12 No.1 Januari 2012. Universitas Lampung. Hal 3
}

masyarakat. Sehingga tidak dapat dipungkiri jika dalam prakteknya akan terjadi kasus pelanggaran hukum seperti penyuapan kepada hakim maupun aparat penegak hukum lainnya, jual beli perkara pidana dan juga disebut praktek mafia peradilan. Permasalahan penanggulangan mafia peradilan berkaitan dengan masalah apakah ada problem konseptual juridis dan sejauhmana sistem peradilan pidana yang integral untuk memperkuat indepedensi peradilan. ${ }^{6}$ Oleh karena itu, Komisi Yudisial sebagai lembaga yang mampu melakukan kontrol secara eksternal terhadap hakim dan lembaga peradilan. ${ }^{7}$

\section{PERMASALAHAN}

Berdasarkan hal-hal yang telah diungkapkan dalam latar belakang, maka dibuat rumusan masalah sebagai berikut :

1. Bagaimana upaya peradilan yang dilakukan oleh Mahkamah Agung dan Mahkamah Konstitusi dalam menjalankan kekuasaan kehakiman

\footnotetext{
${ }^{6}$ Ibid, hal 4

${ }^{7}$ Muzayyin Mahbub. Menegakan Wibawa Hakim (Kerja Komisi Yudisial Mewujudkan Peradilan Bersih dan Bermartabat). Jakarta : Komisi Yudisial editorial. Tahun 2009. hal. ii
} 
dan mewujudkan keadilan di Indonesia?

2. Bagaimana kedudukan kekuasaan kehakiman dalam Sistem Peradilan Pidana yang Terpadu (Integrated Criminal Justice System )?

\section{METODE PENELITIAN}

Metode pendekatan yang digunakan dalam penulisan ini adalah dengan yuridis normatif. Pendekatan tersebut dimaksudkan jenis penelitian dogmatis dan bentuk penelitian perskriptif dalam hubungan pada hukum-hukum. Selanjutnya spesifikasi penelitian ini yaitu deskriptif-analitis, yakni dengan memberikan gambaran terhadap masalah yang diangkat dan memberikan analisis dari masalah sehingga mampu memberikan jawaban atas permasalahan tersebut.

Metode pengumpulan data dalam penelitian ini adalah menggunakan metode kepustakaan (library research) dengan maksud menguji bahan-bahan dokumen dan bahan pustaka yang digunakan dalam penelitian ini. Data dianalisis secara kualitatif-normatif, yaitu melakukan penelitian dengan jalan menafsirkan dan membangun pernyataan yang terdapat dalam dokumen peraturan perundangundangan. Metode analisis kualitatif, dibangun berdasarkan data dan substansinya yang berasalah atau bersumber dari berbagai literatur seperti buku, jurnal, dan karya ilmiah, peraturan perundang-undangan, dan data primer yang diperoleh dari wawancara, pengamatan dan studi lapangan. Selanjutnya dari bahan-bahan tersebut akan dianalisis dengan normatifnya sebagaimana diatur dalam undang-undang, teori dan pendapatpendapat para ahli hukum yang berhubungan dengan kajian kekuasaan kehakiman pada sistem peradilan pidana di Indonesia.

\section{PEMBAHASAN}

A. Upaya Peradilan Yang Dilakukan

Oleh Mahkamah Agung Dan Mahkamah Konstitusi Dalam Menjalankan Kekuasaan Kehakiman Dan Mewujudkan Keadilan Di Indonesia

Kekuasaan kehakiman adalah kekuasaan yang merdeka untuk menyelenggarakan peradilan guna menegakkan hukum dan keadilan. $^{8}$ Dalam pengertian lain menyatakan

\footnotetext{
${ }^{8}$ Pasal 24 Ayat (1) Undang-Undang Dasar 1945
} 
bahwa kekuasaan kehakiman adalah kekuasaan negara yang merdeka untuk menyelenggarakan peradilan guna menegakkan hukum dan keadilan berdasarkan Pancasila dan UndangUndang Dasar 1945, demi terselenggaranya Negara Hukum Republik Indonesia. ${ }^{9}$ Penyelenggaraan kekuasaan kehakiman dalam mewujudkan keadilan melalui peradilan harus berdasar pada ketentuan yang ada dalam undang-undang. Kekuasaan kehakiman harus bersifat merdeka (independent) artinya kekuasaan tersebut tidak dipengaruhi oleh kekuasaan pemerintah, sehingga harus diadakan jaminan dalam undangundang tentang kedudukan para hakim. Jika dikaitkan dengan asas Negara Hukum (rechtstaat) msks dengan adnaya badan pemegang kekuasaan seperti Mahkamah Agung ini tak alin sebagai penegasan bahawa Indonesia ingin memnuhi syarat sebagai Negara hukum. Karena salah satu syarat bagi Negara Hukum adalah adanya peradilan yang bebas dan tidak terpengaruh kekuasaan lain serta tidak memihak (fair and impartial). Kekuasaan

\footnotetext{
9 Pasal 1 butir 1 Undang-Undang 48 Tahun 2009 Tentang Kekuasaan Kehakiman
}

kehakiman dari peradilan adalah kekuasaan untuk memeriksa dan mengadili serta memberikan putusan atas perkara-perkara yang diserahkan kepadanya untuk menegakkan hukum dan keadilan berdasarkan perundangundangan. ${ }^{10}$

Pencantuman

kekuasaan

kehakiman dalam Undang-Undang 1945 berkaitan erat dengan kekuasaan negara dalam suatu negara yang merdeka dan berdaulat dimana menurut ajaran Montesquieu, terdapat tiga macam kekuasaan dalam negara yang harus dipisahkan, yaitu:

1. Kekuasaan legislatif, yang merupakan kekuasaan untuk membentuk peraturan perundangundangan;

2. Kekuasaan eksekutif, yang merupakan kekuasaan untuk melaksanakan peraturan perundangundangan;

3. Kekuasaan yudikatif, yang merupakan kekuasaan untuk menegakkan atau mengadili terhadap pelanggaran peraturan perundangundangan.

10 Yosaphat Bambang Suhendra. Kekuasaan Kehakiman Pasca Amandemen UUD 1945. Tesis. Universitas Diponegoro. Tahun 2008 
Kekuasaan kehakiman merupakan kekuasaan yudikatif dimana kekuasaan tersebut harus bebas dari pengaruh kekuasaan lain (eksekutif ataupun legislatif). ${ }^{11}$ Kekuasaan kehakiman dijalankan dan dipegang oleh badan peradilan, hal ini sesuai dalam teori maupun ketentuan dalam peraturan perundang-undangan. Badan peradilan di Indonesia yang menjalankan kekuasaan kehakiman berdasarkan hasil amandemen Undang-Undang Dasar 1945 adalah Mahkamah Agung, Mahkamah Konstitusi dan pengadilanpengadilan tingkat lebih rendah yang di bawah Mahkamah Agung. ${ }^{12}$ Ketentuan tersebut juga di atur secara eksplisit di dalam Undang-Undang Dasar 1945 Pasal 24 Ayat (2) berbunyi “ kekuasaan kehakiman dilakukan oleh sebuah Mahkamah Agung dan badan peradilan yang berada dibawahnya dalam lingkungan peradilan umum, lingkungan peradilan agama, lingkungan peradilan militer,

11 Bambang Dwi Baskoro, Bunga Rampai Penegakan Hukum Pidana (PANCASILA). Semarang: Badan penerbit Universitas Diponegoro. Tahun 2001. hal. 236

12 Bagir Manan, Hubungan Ketatanegaraan Mahkamah Agung dan Mahkamah Konstitusi dengan Komisi Yudisial. Varia Peradilan, Majalah Hukum. Tahun ke XXQ No. 244 Maret 2006 lingkungan peradilan tata usaha negara, dan oleh sebuah Mahkamah Konstitusi”.

Pemahaman secara luas mengenai kekuasaan kehakiman ini tidak hanya berarti "kekuasaan mengadili" (kekuasaan menegakkan hukum di badan-badan pengadilan), tetapi mencakup kekuasaan menegakkan hukum dalam seluruh proses penegakan hukum. Dalam perspektif Sistem Peradilan Pidana (SPP), "kekuasaan kehakiman (kekuasaan penegakan hukum) di bidang hukum pidana" mencakup seluruh kekuasaan/kewenangan dalam menegakkan hukum pidana, yaitu "kekuasaan penyidikan" (oleh badan/lembaga penyidik), "kekuasaan penuntutan" (oleh badan/lembaga penuntut umum), "kekuasaan mengadili" (oleh badan pengadilan), dan "kekuasaan pelaksana putusan/pidana" (oleh badan/lembaga eksekusi). Dengan demikian, "kekuasaan kehakiman (di bidang hukum pidana)" rdilaksanakan oleh 4 (empat) badan/lembaga seperti yang dikemukakan di atas. Keempat badan 
itulah yang disebut sebagai "badanbadan kehakiman". 13

\section{Menurut}

Soehardjo

Sastrosoehardjo, menerangkan bahwa permasalahan yang klasik ialah bagaimana membentuk sistem peradilan pidana yang benar-benar independen dan bebas dari campur tangan pihakpihak di luar kekuasaan kehakiman. ${ }^{14}$ Dalam permasalahan tersebut bertolak dari asumsi bahwa peradilan tingkat pertama dan tingkat banding secara organisatoris administratif dan finansial berada dibawah pengaturan suatu departemen atau lembaga eksekutif, pasti para hakim tidak bebas atau independen dalam memeriksa dan mengadili perkaradan tidak dapat menjamin bahwa keputusan yang dijatuhkan adalah keputusan yang adil atau sebaliknya.

Kewenangan yang dimiliki dalam menjalankan kekuasaan kehakiman telah di atur dalam peraturan perundang-undangan, mulai dari

13 Barda Nawawi Arief. Kebijakan Penanggulangan Kejahatan. Bandung: PT. Citra Aditya Bakti. Tahun 2001. hal 27-28

14 Soehardjo Sastrosoehardjo. "Seminar Nasional Tentang Kekuasaan Kehakiman dan Sistem Peradilan di Indonesia: "Kekuasaan Kehakiman dan Sistem Peradilan Pidana di Indonesia". FH UNDIP Semarang, 20 November 1996. hal. 2
Undang-Undang Dasar 1945, UndangUndang Nomor 48 Tahun 2009 Tentang Kekuasaan Kehakiman dan undangundang lain yang isinya mengatur hal yang serupa yaitu kekuasaan kehakiman, pada dasarnya menyebutkan bahwa Mahkamah Agung dan badan peradilan dibawahnya serta Mahkamah Konstitusi merupakan lembaga yang menjalankan kekuasaan kehakiman. Mahkamah Agung adalah pengadilan negara tertinggi dari semua lingkungan peradilan yang dalam melaksanakan tugasnya terlepas dari pengaruh pemerintah dan pengaruh-pengaruh lain. ${ }^{15}$ Oleh karena itu, Mahkamah Agung melakukan pengawasan tertinggi terhadap badan peradilan dalam lingkungan peradilan umum, lingkungan peradilan agama, lingkungan peradilan militer, dan lingkungan peradilan tata usaha negara. ${ }^{16}$

\section{Mahkamah Agung mempunyai} wewenang di dalam melaksanakan tugas pokok dan fungsinya untuk menegakkan hukum dan keadilan.

15 Pasal 2 Undang-Undang Nomor 14 Tahun 1985 Tentang Mahkamah Agung.

16 Penjelasan umum dalam Undang - Undang Nomor 3 Tahun 2009 Tentang Mahkamah Agung 
Mahkamah Agung berwenang mengadili pada tingkat kasasi, menguji peraturan perundang-undangan di bawah undang-undang terhadap undang-undang, dan mempunyai wewenang lainnya yang diberikan oleh undang-undang. ${ }^{17}$ Sebagai badan peradilan tertinggi berarti mempunyai konsekuensi yang dimiliki oleh Mahkamah Agung berdasarkan dalam perundang-undangan, bahwa terkait organisasi, administrasi dan finansial Mahkamah Agung dan badan peradilan yang berada di bawahnya berada di bawah kekuasaan Mahkamah Agung. Menurut Barda Nawawi Arief ${ }^{18}$, bahwa Mahkamah Agung dapat diterapkan sebagai "pejabat pengendali" sebab menurut Pasal 24 ayat (1) UndangUndang Dasar 1945, Mahkamah Agung-lah yang ditugasi melaksanakan fungsi "kekuasaan kehakiman" tidak hanya diartikan sebagai "kekuasaan mengadili" akan tetapi lebih luas lagi yaitu sebagai "kekuasaan untuk menegakkan hukum atau undangundang”. Sehingga Mahkamah Agung tidak hanya berfungsi mengawasi penegakan hukum oleh badan-badan

\footnotetext{
${ }^{17}$ Pasal 24 A Ayat (1) Undang - Undang Dasar 1945 amandemen ke IV

${ }^{18}$ Loc. cit
}

pengadilan tetapi juga mengawasi seluruh proses penegakan hukum yang dilakukan mulai dari proses penyidikan, penuntutan samapai pada putusan pengadilan dijatuhkan dan dilaksanakan atau dieksekusi.

Pelaksanaan peradilan oleh Mahkamah Agung berkaitan dengan fungsi dan tugas pokok secara jelas telah dinyatakan di dalam ketentuan perundang - undangan, di bawah ini beberapa fungsi yang dimiliki oleh Mahkamah Agung, antara lain : ${ }^{19}$
a. Fungsi Peradilan
b. Fungsi Pengawasan
c. Fungsi Mengatur
d. Fungsi Nasehat
e. Fungsi Administratif

Berdasarkan ketentuan yang tercantum dalam Undang-Undang Dasar 1945, bahwa kekuasaan kehakiman selain diamanatkan oleh Mahkamah Agung dan badan-badan peradilan di bawahnya (lingkungan peradilan umum, lingkungan peradilan agama, lingkungan peradilan militer dan lingkungan peradilan tata usaha negara), juga dimiliki oleh badan peradilan tinggi yaitu Mahkamah Konstitusi. Mahkamah Konstitusi adalah salah satu

\footnotetext{
${ }^{19}$ http://dede-fahla.blogspot/2011/10/fungsi-dantugas-mahkamah-agung.html (accesed: 9 Oktober 2013. Pukul 6.11 WIB).
} 
kekuasaan kehakiman sebagaimana dimaksud dalam Undang-Undang Dasar Negara Republik Indonesia Tahun 1945. ${ }^{20}$ Sebagai pelaku kekuasaan kehakiman, maka Mahkamah Konstitusi memiliki tugas pokok dan fungsinya yang juga di atur di dalam peraturan perundang-undangan. Merupakan sebuah angin segar dengan adanya cabang kekuasaan kehakiman yaitu lahirnya Mahkamah Konstitusi. Jika bertolak dari Pasal 24 ayat (2) UndangUndang Dasar 1945, dengan terbentuknya cabang kekuasaan kehakiman merupakan satu kesatuan sistem yang dilakukan oleh Mahkamah Agung dan Mahkamah Konstitusi yang mencerminkan puncak kedaulatan hukum Indonesia yang berdasarkan Undang-Undang Dasar 1945 pada bulan Agustus tahun 2003. Mahkamah Konstitusi Republik Indonesia kemudian diatur di dalam UndangUndang Nomor 24 Tahun 2003. ${ }^{21}$ Namun lembaga Mahkamah Konstitusi sendiri baru benar-benar terbentuk pada tanggal 17 Agustus 2003 setelah

20 Pasal 1 Undang-Undang Nomor 8 Tahun 2011 Tentang Mahkamah Konstitusi

${ }^{21}$ Lembaran Negara Republik Indonesia Tahun 2003 Nomor 98, Tambahan Lembaran Negara Republik Indonesia No. 4316 pengucapan sumpah jabatan oleh sembilan hakim konstitusi pada tanggal 16 Agustus 2003. ${ }^{22}$

Wewenang yang diberikan kepada Mahkamah Konstitusi dalam menjalankan kekuasaan kehakiman di Indonesia sebagimana di atur dalam Pasal 24 C ayat (1) Undang-Undang Dasar 1945, Mahkamah Konstitusi berwenang mengadili pada tingkat pertama dan terakhir yang putusannya bersifat final untuk menguji undangundang terhadap Undang-Undang Dasar 1945, memutus sengketa kewenangan lembaga negara yang kewenangannya diberikan oleh Undang-Undang Dasar 1945, memutus pembubaran partai politik, dan memutus perselisihan tentang hasil pemilu. Selain kewenangan tersebut, bahwa Mahkamah Konstitusi juga wajib memberikan putusan atas pendapat Dewan Perwakilan Rakyat bahwa Presiden dan/atau Wakil Presiden diduga telah melakukan pelanggaraan hukum berupa pengkhianatan terhadap negara, korupsi, penyuapan, tindak pidana, berat lainnya, atau perbuatan

22 Berdasarkan pada Keputusan Presiden Np. 147/ M Tahun 2003, tanggal 15 Agustus 2003 
tercela, dan/atau tidak lagi memnuhi syarat sebagai presiden dan/atau wakil presiden sebagaimana dimaksud dalam Undang-Undang Dasar 1945. ${ }^{23}$

Sebagaimana yang di atur dalam Undang-Undang Dasar 1945 mengenai kekuasaan kehakiman yang telah dijelaskan di atas, bahwa Mahkamah Agung dan Mahkmah Konstitusi mempunyai kedudukan yang sama dalam lembaga negara, popularitas Mahkamah Agung lebih dikenal oleh masyarakat jika dibandingkan dengan Mahkamah Konstitusi. Faktor lain kekurang populeran Mahkamah Konstitusi mungkin dikarenakan umur dari keberadaan (eksistensi) Mahkamah Konstitusi yang relatif lebih muda dari Mahkamah Agung.

Meskipun demikian, pada intinya kedua lembaga peradilan tertinggi di Indonesia tersebut mempunyai tujuan yang sama dalam menegakkan prinsipprisnsip yang terkandung dalam paham negara hukum, serta tetap berlandaskan pada Undang-Undang Dasar 1945 untuk menwujudkan keadilan bagi seluruh rakyat Indonesia. Jika penyelenggaraan peradilan di Indonesia dilakukan dengan

${ }^{23}$ Pasal 24C ayat (2) UUD 1945, juncto Pasal 10 ayat 92) dan (3) Undang - Undang Nomor 24 Tahun 2003 tentang Mahkamah Konstitusi. berdasar pada penegakan hukum yang memakai cara-cara kotor dan tercela atau mafia peradilan, maka akan terjadi rasa ketidakpercayaan masyarakat terhadap penegakan hukum yang sedang terjadi. Menurut Alfian, ${ }^{24}$ bahwa krisis kepercayaan terhadap hukum menyebabkan melemahnya partisipasi masyarakat dalam bidang hukum yang disebabkan karena faktor sebagai berikut:

1. Kurangnya pengetahuan warga masyarakat akan peraturanperaturan yang ada;

2. Kekurangpercayaan akan kemampuan hukum untuk menjamin hak-hak dan kewajiban-kewajiban mereka secara adil;

3. Materi peraturan hukum kurang sesuai atau bahkan bertentangan dengan nilai-nilai yang dianut oleh masyarakat;

4. Para pelaksana atau penegak hukum kurang atau tidak memberi contoh yang baik dalam kepatuhannya terhadap hukum.

\footnotetext{
${ }^{24}$ Lihat dalam bukunya Sidik Sunaryo. Kapita Selekta Sistem Peradilan Pidana. Malang: UMM Pers. Tahun 2005,. hal. 9-10
} 
B. Kedudukan

Kekuasaan

Kehakiman Dalam Sistem

Peradilan Pidana Yang Terpadu

(Integrated Criminal Justice

System )

Badan-Badan peradilan yang menjadi pelaksana kekuasaan kehakiman yang telah dijelaskan secara lengkap di atas dengan acuan pada peraturan perundang-undangan, mulai Undang-Undang Dasar 1945 dan juga undang-undang lain yang mengatur hal sama telah memberikan banyak peranan serta kedudukan dalam mewujudkan penegakan hukum khususnya Indonesia. Pembahasan yang lebih khusus mengenai lembaga peradilan sebagai lembaga penegakan hukum dalam sistem peradilan pidana (criminal justice system), merupakan suatu tumpuan harapan dari para pencari keadilan yang selalu menghendaki peradilan yang sederhana, cepat, dan biaya ringan. Keadilan yang hakiki merupakan suatu syarat yang utama untuk mempertahankan kelangsungan hidup suatu masyarakat, dalam hal hakim mempunyai suatu peranan penting dalam penegakan hukum pidana untuk tercapainya suatu keadilan yang diharapkan dan dicita-citakan. ${ }^{25}$

Menurut Sudikno Mertokusumo menyatakan, bahwa eksistensi hakim sebagai alat penegak hukum di Indonesia dewasa ini mempunyai suatu persepsi yang negatif dari masyarakat, hal tersebut dikarenakan banyak sekali putusan-putusan hakim yang tidak sesuai dengan harapan masyarakat. Disamping itu juga karena semakin kompleksnya bentuk dari kejahatan yang terjadi yang belum ada pengaturannya di dalam undang-undang hukum pidana sehingga apa yang menjadi tujuan hukum pidana tidak tercapai dengan ruang lingkup sistem peradilan pidana. $^{26}$ Perlu adanya pembenahan dari sistem yang ada saat ini terutama pada kebijakan pengembangan atau peningkatan kualitas peradilan terkait dengan berbagai aspek yang mempengaruhi kualitas peradilan atau penegakan hukum.

\footnotetext{
${ }^{25}$ Yesmil Anwar dan Adang. Sistem Peradilan Pidana (Konsep, Komponen dan Pelaksanaannya dalam Penegakan Hukum di Indonesia). Bandung: Widya Padjajaran. Tahun 2011. Hal. 218

${ }^{26}$ Sudikno Mertokusumo dan A. Pitlo. Bab-bab Tentang Penemuan Hukum. Yogyakarta : PT. Citra Aditya Bakti. Tahun 1993. hal, 2
} 
Peningkatan kualitas peradilan di Indonesia dari beberapa aspek diantaranya mencakup kualitas individual Sumber Daya Manusia (SDM), kualitas institusionalnya (kelembagaan), kualitas mekanisme tata kerja (manajemen), kualitas sarana dan prasarana, kualitas substansi hukum (perundang-undangan) dan kualitas lingkungan (kondisi sosial, ekonomi, politik, budaya, termasuk budaya hukum masyarakat). Dengan demikian, upaya penungkatan kualitas peradilan atau penegakan hukum harus mencakup keseluruhan aspek/kualitas yang mempengaruhi kualitas peradilan tersebut. ${ }^{27}$

Pengadilan selama ini dijadikan sebagai suatu simbolik bagi masyarakat untuk mencapai tujuan-tujuan hukum khususnya keadilan dari permasalahan atau sengketa-sengketa hukum yang harus diselesaikan. Supremasi hukum akan dapat berjalan secara maksimal tatkala komponen-komponen dalam penegakan hukum yang tersistem ke dalam bentuk sistem peradilan pidana yang integral. Menilik dari satu komponen penegakan hukum yang dilaksanakan oleh badan-badan

27 Barda Nawawi Arief. Op. Cit. hal. 33-34 peradilan belum maksimal dan optimal dalam menghayati kebebasan kekuasaan kehakiman dalam konteks peradilan mandiri, tidak menyatu atapkan pembinaan dan pengawasan, tapi juga dmaksudkan untuk memandirikan hakim dan lembaga Mahkamah Agung serta badan-badan peradilan dibawahnya dan juha Mahkamah Konstitusi. Kemandirian kekuasaan kehakiman merujuk pada teorinya Montesqueiu mengenai pemisahan kekuasaan antara kekuasaan legislatif, eksekutif dan yudikatif. Dengan demikian itu, agar dapat terciptanya suatu check and balances dalam sistem politk.

Peradilan yang mandiri tanpa ada intervensi atau campur tangan dari pihak lain, diharapkan agar keadilan yang diberikan hakim benar-benar sesuai kemauan dan kebenaran materiil dengan terwujudnya keadilan bagi masyarakat. Dalam hal ini, terdapat alasan mengapa harus ada penegasan bahkan jaminan dan perlindungan kemerdekaan atau kebebasan kekuasaan kehakiman, antara lain $:^{28}$

a) Bahwa secara natural,

${ }^{28}$ Bagir Manan, op. cit. hal. 6 


\begin{tabular}{llr} 
sekuat & bahkan & lemah \\
dibandingkan & dengan & cabang \\
kekuasaan & lain. & Tanpa \\
penegasan, & jaminan & an \\
perlindungan, & \multicolumn{2}{r}{ kekuasaan } \\
kehakiman & tidak & berdaya \\
menghadapi & & kekuasaan- \\
kekuasaan lain. & &
\end{tabular}

b) Kekuasaan kehakiman yang merdeka diperlukan untuk menjamin "impartiality" dan "fairness" dalam memutus perkara, termasuk perkaraperkara yang langsung atau tidak langsung melibatkan kepentingan cabang kekuasaan yang lain.

c) Kekuasaan kehakiman yang merdeka, dipandang sebagai unsur penting bahkan sebagai ciri substantif sebuah negara hukum dan demokrasi atau negara hukum demokratis (democratische rechtstaat).

Menurut Barda Nawawi Arief, menyatakan bahwa sistem peradilan pada hakikatnya identik dengan sistem penegakan hukum, karena proses peradilan pada hakikatnya suatu proses penegakan hukum. Jadi pada hakikatnya identik dengan "sistem kekuasaan kehakiman", karena kekuasaan kehakiman pada dasarnya merupakan "kekuasaan atau kewenangan menegakkan hukum". Apabila difokuskan dalam bidang hukum pidana, dapat dikatakan bahwa "sistem peradilan pidana" (dikenal dengan istilah SPP atau "Criminal Justice System/ CJS" pada hakikatnya juga identik dengan "Sistem Kekuasaan Kehakiman di bidang Hukum Pidana" (SKK HP). ${ }^{29}$ Sistem peradilan (sistem penegakan hukum) dilihat secara integral, merupakan satu kesatuan berbagai sub-sistem (komponen) yang terdiri dari komponen "susbtansi hukum" (legal culture), "struktur hukum" (legal structure) dan "budaya hukum" (legal culture).

Sistem Peradilan Pidana yang integral seperti yang dikemukakan oleh Sanford H. Kadish dapat dilihat dari tiga aspek yaitu (1) sebagai sistem normatif (normative system); (2) sistem administratif (administrative system); dan (3) sistem sosial (social system). ${ }^{30}$ Bertolak dari pengertian sistem integral tersebut, Barda Nawawi Arief menyatakan bahwa pengertian sistem peradilan $(\mathrm{SPH})$ dapat dilihat dari berbagai aspek $:^{31}$

\footnotetext{
${ }^{29}$ Lihat dalam bahan kuliah "Sistem Peradilan Pidana (Criminal Justice System)" oleh Nyoman Serikat Putra Jaya. Universitas Diponegoro Semarang, tanpa tahun. hal. 16 ${ }^{30}$ Ibid. hal. 17

31 Barda Nawawi Arief. Reformasi Sistem Peradilan (Sistem Penegakan Hukum) di Indonesia. Dalam Bunga Rampai = Potret Penegakan Hukum di Indonesia. Komisi Yudisial RI. Tahun 2009. hal. 184-186
} 
a. Aspek/ komponen substansi hukum (legal substance), sistem peradilan pada hakikatnya merupakan suatu sistem penegakan substansi hukum (bidang hukum pidana meliputi hukum pidana materiil, hukum pidana formil dan hukum pelaksanaan pidana).

b. Aspek/ komponen struktural (legal structure) sistem peradilan pada dasarnya merupakan sistem bekerjanya/ fungsinya badan-badan/ lembaga/ aparat penegak hukum dalam melaksanakan, menjalankan fungsi/ kewenangannya masing-masing di bidang penegakan hukum.

c. Aspek/ komponen budaya hukum (legal culture), sistem peradilan pada dasarnya merupakan perwujudan dari sistem "nilai-nilai budaya hukum" (yang mencakup filsafat hukum, asas-asas hukum, teori hukum, ilmu hukum dan kesadaran hukum, sikap perilaku hukum).

Menurut Muladi, bahwa sistem peradilan pidana adalah suatu jaringan (network) peradilan yang menggunakan hukum pidana materiil, hukum pidana formil maupun hukum pelaksanaan pidana. Namun kelembagaan ini harus dilihat dalam konteks sosial. Sifat yang terlalu formal jika dilandasi hanya untuk kepentingan kepastian hukum saja akan membawa bencana ketidakadilan. $^{32}$ Sebagaimana telah dikemukakan tersebut, bahwa hakim sebagai salah satu komponen dalam sistem peradilan pidana mempunyai peranan dari pengaruhnya yang sangat besar terhadap keberhasilan penegakan hukum, diharapkan dapat bekerjasama dan membentuk suatu "Integrated Criminal Justice" dengan komponenkomponen sistem peradilan pidana lainnya, untuk mencapai keberhasilan dalam penegakan. Selain itu, sebagaimana dikemukakan oleh Mardjono Reksodiputro, yang mengatakan: ${ }^{33}$

"Keempat komponen dalam sistem peradilan pidana (kepolisian, kejaksaan, pengadilan dan lembaga pemasyarakatan) diharapkan dapat bekerjasama dan dapat membentuk suatu "Integrated Criminal Justice System". Apabila keterpaduan dalam bekerjanya sistem tidak dilakukan, diperkirakan akan terdapat tiga kerugian sebagai berikut:

1. Kesukaran dalam menilai sendiri keberhasilan atau kegagalan

32 Romli Atmasasmita. Sistem Peradilan Pidana, Perspektif Eksistensialisme dan Abolisionisme. Bandung: Bina Cipta. Tahun 1996. hal. 16

33 Ibid., hal. 16. Lihat sumber utamanya, Mardjono Reksodiputro, Sistem Peradilan Pidana Indonesia (melihat kepada kejahatan dan penegakan hukum dalam batas-batas toleransi).pidato pengukuhan penerimaan jabatan Guru Besar tetap dalam Ilmu Hukum pada Fakultas Hukum Indonesia. Tahun 1993 
masing-masing instansi, sehubungan dengan tugas mereka bersama;

2. Kesulitan dalam memecahkan sendiri masalah-masalah pokok masing-masing instansi (sebagai sub-sistem dari sistem peradilan pidana), dan

3. Karena tanggungjawab masingmasing instansi sering kurang jelas terbagi, maka setiap instansi tidak terlalu memperhatikan efektifitas menyeluruh dari sistem peradilan pidana.

Dalam penegakan hukum yang juga berhubungan dengan kekuasaan kehakiman, maka peran yang utama yaitu hakim-hakim pengadilan. Berkaitan dengan fungsi dan kedudukan hakim dalam proses peradilan pidana, Soerjono Soekanto, ${ }^{34}$ membedakannya kepada dua fungsi penting yaitu fungsi yang ideal dan fungsi yang seharusnya. Pertama, fungsi yang ideal yaitu berdasarkan pada ketentuan yang ada di dalam peraturan perundang-undangan yang berlaku (Pasal 1 Undang-Undang Nomor 4 Tahun 2004 tentang Kekuasaan Kehakiman). Kedua, fungsi yang seharusnya yaitu berdasarkan ketentuan di dalam Pasal 1, Pasal 4 ayat (2), Pasal 5 ayat (1) dan (2) dan Pasal

34 Soerjono Soekanto. Faktor-faktor yang Mempengaruhi Penegakan Hukum. Jakarta: Rajawali. Tahun 1986. hal. 18
16 ayat (1) Undang-Undang Kekuasaan Kehakiman. Dengan demikian dapat dikatakan bahwa hakim sebagai salah satu komponen sistem peradilan pidana dampak hasil kerjanya tidak dapat diabaikan atau dilepaskan dari komponen lainnya dalam proses peradilan pidana. Sehingga setiap masalah yang timbul dalam salah satu komponen sistem peradilan pidana, misalnya hakim, maka akan menimbulkan dampak pula pada komponen-komponen yang lainnya. Reaksi yang timbul sebagai akibat dari hal ini akan menimbulkan dampak kembali pada komponen atau sub sistem awal dan demikian pula selanjutnya secara terus menerus, yang pada akhirnya tidak akan ada suatu kejelasan mana yang merupakan sebab dan mana yang merupakan akibat.

\section{KESIMPULAN}

Berdasarkan hasil penelitian dan pembahasan maka dapat disimpulkan penelitian ini sebagai berikut:

1. Kekuasaan kehakiman telah ditegaskan di dalam Pasal 24 ayat (1) Undang-Undang Dasar 1945 bahwa kekuasaan kehakiman merupakan kekuasaan yang merdeka untuk menyelenggarakan 
peradilan guna menegakkan hukum dan keadilan. Dalam melaksanakan kekuasaan kehakiman telah dimiliki oleh sebuah Mahkamah Agung dan badan pengadilan yang berada dibawahnya dalam lingkungan peradilan umum, lingkungan peradilan agaman, limgkungan peradilan militer dan lingkungan peradilan tata usaha negara. Badan peradilan yang tertinggi di Indonesia terdapat Mahkamah Agung dan Mahkamah Konstitusi yang masing-masing mempunyai kewenangan-kewenangan sendiri. Mahkamah Agung berwenang mengadili pada timgkat kasasi, menguji peraturan perundangundangan di bawah undangundang terhadap undang-undang dan mempunyai wewenang lain yang diberikan oleh undangundang. Sedangkan Mahkamah Konstitusi berwenang untuk menguji undang-undang terhadap Undang-Undang Dasar 1945, memutus sengketa kewenangan antar lembaga negara yang kewenangannya diberikan oleh Undang-Undang Dasar 1945, memutus pembubaran partai politik, dan memutus perselisihan tentang hasil pemilu. Selain kewenangan tersebut, bahwa Mahkamah Konstitusi juga wajib memberikan putusan atas pendapat Dewan Perwakilan Rakyat bahwa Presiden dan/atau Wakil Presiden diduga telah melakukan pelanggaraan hukum.

2. Kedudukan kekuasaan kehakiman dalam sistem peradilan pidana sangat berhubungan erat karena mempunyai tujuan - tujuan untuk menegakkan hukum dan mewujudkan keadilan. Sistem peradilan pada hakikatnya identik dengan sistem penegakan hukum, karena proses peradilan pada hakikatnya suatu proses penegakan hukum. Jadi pada hakikatnya identik dengan "sistem kekuasaan kehakiman", karena kekuasaan kehakiman pada dasarnya merupakan "kekuasaan atau kewenangan menegakkan hukum. Sistem peradilan (sistem penegakan hukum) dilihat secara integral, merupakan satu kesatuan berbagai sub sistem (komponen) yang terdiri dari komponen 
“susbtansi hukum” (legal culture),

“struktur hukum" (legal structure)

dan "budaya hukum” (legal

culture).

\section{DAFTAR PUSTAKA}

\section{A. Buku}

Anwar, Yesmil dan Adang. Sistem Peradilan Pidana (Konsep, Komponen dan Pelaksanaannya dalam Penegakan Hukum di Indonesia). Bandung: Widya Padjajaran. 2011

Arief, Barda Nawawi Kebijakan Penanggulangan Kejahatan. Bandung : PT. Citra Aditya Bakti. 2001 Reformasi Sistem Peradilan (Sistem

Penegakan Hukum) di Indonesia. Dalam Bunga Rampai $=$ Potret Penegakan Hukum di Indonesia. Komisi Yudisial RI. 2009

Atmasasmita, Romli. Sistem Peradilan Pidana, Perspektif Eksistensialisme dan Abolisionisme. Bandung: Bina Cipta. 1996

Baskoro, Bambang Dwi. Bunga Rampai Penegakan Hukum Pidana (PANCASILA). Semarang : Badan penerbit Universitas Diponegoro. 2001

Daradono, Donny. Uang, Ideologi, Jabatan dalam Mafia Peradilan, Reduksi terhadap The Political. Jurnal Kajian Politik Lokal dan Studi Humaniora. Salatiga : Yayasan Percik. 2007

Jaya, Nyoman Serikat Putra . Bahan kuliah "Sistem Peradilan Pidana (Criminal Justice System)" Universitas Diponegoro Semarang, tanpa tahun 
Muladi, Kapita Selekta Sistem Peradilan Pidana,

Semarang : Badan penerbit UNDIP. 1995

Mahbub, Muzayyin. Menegakan Wibawa Hakim (Kerja Komisi Yudisial Mewujudkan Peradilan Bersih dan Bermartabat). Jakarta : Komisi Yudisial editorial. 2009

Manan, Bagir. Hubungan Ketatanegaraan Mahkamah Agung dan Mahkamah Konstitusi dengan Komisi Yudisial. Varia Peradilan, Majalah Hukum. Tahun ke XXQ No. 244 Maret 2006

Mertokusumo, Sudikno dan A. Pitlo. Bab-bab Tentang Penemuan Hukum. Yogyakarta : PT. Citra Aditya Bakti. 1993

Reksodiputro, Mardjono, Sistem Peradilan Pidana Indonesia (melihat kepada kejahatan dan penegakan hukum dalam batas-batas toleransi).pidato

pengukuhan penerimaan jabatan Guru Besar tetap dalam Ilmu Hukum pada Fakultas Hukum Indonesia. 1993

Mardjono. Hak Asasi Manusia dalam Sistem Peradilan Pidana. Jakarta : Pusat Pelayanan Keadilan dan Pengabdian Umum (Universitas Indonesia). 1994

Subekti dan Tjitrosoedibio. Kamus Hukum. Jakarta : Pradya Paramita. 1972,

Suhendra, Yosaphat Bambang. Kekuasaan Kehakiman Pasca Amandemen UUD
1945. Tesis. Universitas Diponegoro. 2008

Sastrosoehardjo, Soehardjo. "Seminar Nasional Tentang Kekuasaan Kehakiman dan Sistem Peradilan di Indonesia: "Kekuasaan Kehakiman dan Sistem Peradilan Pidana di Indonesia". FH UNDIP Semarang, 20 November 1996

Sunaryo, Sidik. Kapita Selekta Sistem Peradilan Pidana. Malang: UMM Pers. 2005

Soekanto, Soerjono. Faktor-faktor yang Mempengaruhi Penegakan Hukum. Jakarta: Rajawali. 1986

Widodo, J. Pajar. Reformasi Sistem Peradilan Pidana Dalam Rangka Penanggulangan Mafia Peradilan. Jurnal Dinamika Hukum Vol 12 No.1. Universitas Lampung. Januari 2012

\section{B. Peraturan Perundang-undangan}

Undang-Undang Dasar Negara Republik Indonesia Tahun 1945

Undang-Undang Nomor 3 Tahun 2009 Tentang Mahkamah Agung

Undang-Undang 48 Tahun 2009 Tentang Kekuasaan Kehakiman 